University of South Florida

DIGITAL COMMONS

Digital Commons @ University of

@ UNIVERSITY OF SOUTH FLORIDA

South Florida

School of Geosciences Faculty and Staff

Publications

School of Geosciences

1990

\title{
Rupture Process of the Macquarie Ridge Earthquake of May 23, 1989
}

Jochen Braunmiller

Oregon State University, jbraunmiller@usf.edu

John Nábělek

Oregon State University

Follow this and additional works at: https://digitalcommons.usf.edu/geo_facpub

Part of the Earth Sciences Commons

\section{Scholar Commons Citation}

Braunmiller, Jochen and Nábělek, John, "Rupture Process of the Macquarie Ridge Earthquake of May 23, 1989" (1990). School of Geosciences Faculty and Staff Publications. 832.

https://digitalcommons.usf.edu/geo_facpub/832

This Article is brought to you for free and open access by the School of Geosciences at Digital Commons @ University of South Florida. It has been accepted for inclusion in School of Geosciences Faculty and Staff Publications by an authorized administrator of Digital Commons @ University of South Florida. For more information, please contact digitalcommons@usf.edu. 


\title{
RUPTURE PROCESS OF THE MACQUARIE RIDGE EARTHQUAKE OF MAY 23, 1989
}

\author{
Jochen Braunmiller and John Nábělek
}

College of Oceanography, Oregon State University, Corvallis, OR 97331

\begin{abstract}
Broadband body waves recorded at 15 digital seismic stations worldwide are used to study the rupture process of the May 23, 1989 Macquarie Ridge earthquake. The centroidal solution (strike $211^{\circ}$, dip $86^{\circ}$, rake $180^{\circ}$, and depth of $10 \mathrm{~km}$ below the seafloor) indicates shallow rupture with pure right-lateral strike-slip motion along the PacificAustralia plate boundary, in agreement with motion predicted by plate tectonic models. The total seismic moment is $13.4 \times 10^{20} \mathrm{Nm}, 80 \%$ of which was released in the first $24 \mathrm{~s}$ of the rupture process. Modeling favors a bilaterally propagating rupture with slightly different dip and rake for the northward and southward fault segments and similar moment release along both directions. The estimated fault length is quite short, about $90 \mathrm{~km}$, and the derived stress drop of 180 bar and averuge displacement of $17 \mathrm{~m}$ are unusually high. The bathymetry in the epicentral region shows topographic segmentation of the ridge, possibly indicating fault segmentation which confines ruptures to short segments.
\end{abstract}

\section{Introduction}

The Macquarie Ridge earthquake of May 23, 1989 with a surface wave magnitude $\left(M_{s}\right)$ of 8.3 is the largest event worldwide in more than a decade. The focal parameters according to the Preliminary Determination of Epicenters (PDE) catalogue are: latitude $52.3^{\circ} \mathrm{S}$, longitude $160.6^{\circ} \mathrm{E}$, depth $10 \mathrm{~km}$ and origin time $10 \mathrm{~h} 54 \mathrm{~m} 46.3 \mathrm{~s}$. The earthquake occurred in the central part of the Macquarie Ridge Complex (Figure 1), which forms the Pacific-Australia plate boundary and runs approximately north-south for $2000 \mathrm{~km}$ between the South Island of New Zealand and the Pacific-AntarcticAustralia triple junction. Global plate tectonic models place the Pacific-Australia pole of rotation close to the Macquarie Ridge (Minster and Jordan, 1978; DeMets et al., 1990), thus relative plate motions along the plate boundary can change rapidly, which is reflected in its evolution. The region originally formed in an ocean-spreading environment (Molnar et al., 1975) with the youngest radiometrically dated oceanic basalts from Macquarie Island of about $10 \mathrm{Ma}$ age (Duncan and Vame, 1988). Due to the southward migration of the rotation pole ( Molnar et al., 1975; Stock and Molnar, 1982), the ridge subsequently served as a strike-slip plate boundary with the northernmost part (north of $50^{\circ} \mathrm{S}$ ) developing into an oblique convergent boundary (Ruff et al., 1989) where the Australian plate is being subducted beneath the Pacific plate.

Body waves recorded at 15 stations from the Global Digital Seismic Network (GDSN) and the digital networks of the

Copyright 1990 by the American Geophysical Union.

Paper number 90GL01162

0094-8276/90/90GL-01162\$03.00
Incorporated Research Institute for Seismology (IRIS) and GEOSCOPE are used to study the rupture process of the Macquarie Ridge earthquake. First we determine the centroidal parameters: mechanism, depth, seismic moment and the source time history of the rupture. Then we examine if the data show rupture spreading in a unilateral or bilateral fashion away from its nucleation point and estimate the fault length and stress drop.

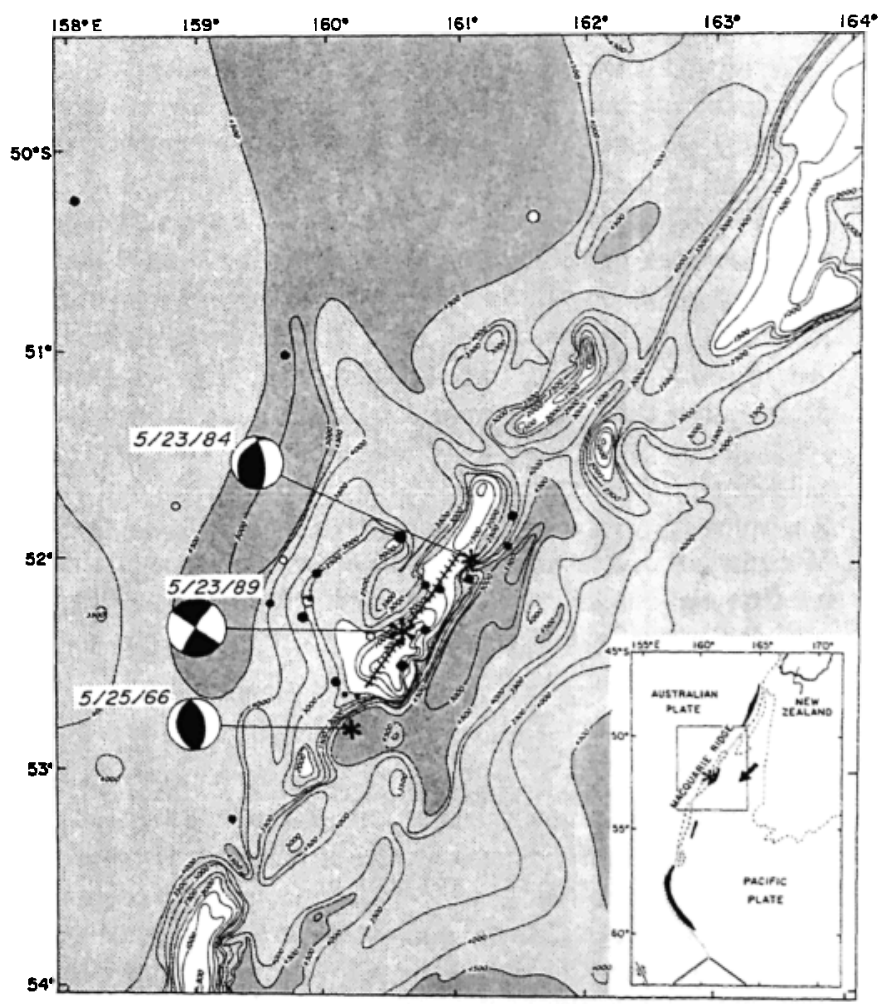

Fig. 1. Bathymetric map of the epicentral area. Epicentral locations and source mechanisms of the 1989 earthquake (large star) and two thrust events 25 May 1966, $M=6.5$ and 23 May $1984, M=5.9$ are shown. The first week of aftershocks is indicated by solid circles and those recorded since then until December 1989 by open circles (only aftershocks recorded by 20 or more stations are depicted; PDE data). The region in which $80 \%$ of the moment release occurred during the 1989 event is dashed. Bathymetry is shown by $500 \mathrm{~m}$ contours. Dark shading indicates areas deeper than $4500 \mathrm{~m}$, light shading $2000-4500 \mathrm{~m}$, and white areas are shallower than $2000 \mathrm{~m}$. Topographic segmentation of the ridge in the epicentral area is apparent. The insert shows a tectonic overview. The arrow indicates the relative plate motion between the Pacific and Australian plates according to the NUVEL-1 model (DeMets et al., 1990). $1800 \mathrm{~m}$ depth contours are dashed, depths greater than $4800 \mathrm{~m}$ are shaded. 


\section{Data and Methods}

The analysis follows the procedures described by Nábĕlek (1984). P and SH body waves recorded by GDSN, IRIS and GEOSCOPE digital stations in the epicentral distance range between $30^{\circ}$ and $100^{\circ}$ for $\mathrm{P}$ waves and $30^{\circ}$ and $90^{\circ}$ for $\mathrm{SH}$ waves are used. In this distance range, the waveforms are not contaminated by strong upper mantle or core phases. The large magnitude of the earthquake caused some seismograms from stations in the above distance range to behave non-linearly; these data were excluded from the analysis. We deconvolved the instrument response to obtain broadband displacement seismograms; depending on the data quality and the seismograph type, the data are broadband from the Nyquist period of $0.6 \mathrm{~s}$ to a period of $100 \mathrm{~s}$ or $200 \mathrm{~s}$. For stations BJI and MDJ, where only long-period data were used to obtain the broadband seismograms, the short-period cutoff is $4 \mathrm{~s}$. Due to a high noise level at station $\mathrm{ZOBO}$ the long-period cutoff is 50 s.

The crustal structure in the source region is assumed to be a half-space overlain by a $3.8 \mathrm{~km}$ thick water layer. At the receivers we chose a crustal half-space. The P- and S-wave velocities of the half space are: $6.0 \mathrm{~km} / \mathrm{s}, 3.46 \mathrm{~km} / \mathrm{s}$, with a rock density of $2.8 \mathrm{~g} / \mathrm{cm}^{3}$. The seismograms are simultaneously inverted in a least-squares sense for the source model parameters. A point source is used to obtain a average (centroidal) description of the source. To examine complexities due to source finiteness and rupture propagation, we used a propagating line source parameterization as described by Nábělek (1984) and Boyd and Nábělek (1988). To investigate such details of the rupture process, it is necessary to precisely determine the arrival times. The onset of many $P$ waves for the Macquarie Ridge earthquake is quite emergent, we determined the first motion using both broadband and high-pass filtered waveforms and by checking for consistency with stations at similar azimuths.

\section{Inversion Results}

The results of our analysis are summarized in Table 1 . The centroidal solution indicates a pure strike-slip mechanism: strike $211^{\circ}$, dip $86^{\circ}$ and rake $180^{\circ}$. The variation of the mismatch between the observed and synthetic seismograms as a function of depth (Figure 2) indicates that the centroid is less than $20 \mathrm{~km}$ below the seafloor. The mechanism in this depth range remains very stable, while the seismic moment varies by about $10 \%$ (Figure 2). The least mismatch is obtained for a point source at $10 \mathrm{~km}$ below the seafloor with a seismic moment of $13.4 \times 10^{20} \mathrm{Nm}$, which corresponds to a moment magnitude $\left(\mathrm{M}_{\mathrm{W}}\right)$ of 8.02 . Following an emergent beginning, about $80 \%$ of the moment is released in a 22 -second-long pulse followed by 3 smaller pulses (Figure 3a). The fit to the data at representative azimuthally distributed stations for the point source model is shown in Figure 4.

The $\mathrm{P}$ waveforms, especially those near the nodes of the radiation pattern (KIP, AFI, RPN, CRZ and PAF), appear to be strongly affected by water reverberations. The bathymetry plays an important role in the character of these waves (Wiens, 1989 ) and our horizontally layered model is probably inadequate in explaining the $\mathrm{P}$-wave seismograms near the nodes. The later part of the source time function shows periodic pulses with the period of the water reverberations, probably
TABLE 1. Source Models Derived by Body Wave Inversion

\begin{tabular}{|c|c|c|c|c|c|c|c|}
\hline & $\begin{array}{l}\text { Moment } \\
10^{20} \mathrm{Nm}\end{array}$ & $\begin{array}{l}\text { Depth } \\
\text { km }\end{array}$ & $\begin{array}{c}\text { Strike } \\
\text { deg }\end{array}$ & $\begin{array}{l}\text { Dip } \\
\text { deg }\end{array}$ & $\begin{array}{l}\text { Rake } \\
\text { deg }\end{array}$ & $\begin{array}{c}\text { Duration } \\
\mathbf{s}\end{array}$ & $\sigma$ \\
\hline PS & 13.4 & 10 & 211 & 86 & 180 & 52 & \\
\hline PSs & 9.7 & $10^{*}$ & $211^{*}$ & $86^{*}$ & $180^{*}$ & 26 & 0.30 \\
\hline USS & 9.3 & $10^{*}$ & $211^{*}$ & $86^{*}$ & $180^{*}$ & 26 & 0.34 \\
\hline USN & 10.2 & $10^{*}$ & $211^{*}$ & $86^{*}$ & $180 *$ & 26 & 0.28 \\
\hline $\begin{array}{l}\text { BS1 } \\
\text { south } \\
\text { north }\end{array}$ & $\begin{array}{l}4.8 \\
5.2\end{array}$ & $\begin{array}{l}10^{*} \\
10^{*}\end{array}$ & $\begin{array}{l}211^{*} \\
211^{*}\end{array}$ & $\begin{array}{l}86^{*} \\
86^{*}\end{array}$ & $\begin{array}{l}180^{*} \\
180^{*}\end{array}$ & $\begin{array}{l}16 \\
28\end{array}$ & 0.26 \\
\hline $\begin{array}{l}\text { BS2 } \\
\text { south } \\
\text { north }\end{array}$ & $\begin{array}{l}4.7 \\
5.5\end{array}$ & $\begin{array}{l}10^{*} \\
10^{*}\end{array}$ & $\begin{array}{l}210 \\
212\end{array}$ & $\begin{array}{l}95 \\
82\end{array}$ & $\begin{array}{l}174 \\
187\end{array}$ & $\begin{array}{l}16 \\
30\end{array}$ & 0.24 \\
\hline
\end{tabular}

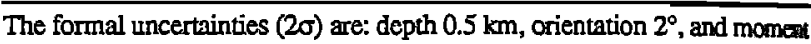
20\%. PS - point source, PSs - point source with duration restricted to main moment release, USS - unilateral rupture towards southwest, USN unilateral rupture towards northeast, BS1 - bilateral rupture with source mechanism fixed, BS2 - bilateral rupture with source mechanism free $\sigma$ normalized variance of residuals. "*" - fixed.

aliasing structural effects into the estimated source time history. Because about $80 \%$ of the seismic moment is released in the first $24 \mathrm{~s}$, we concentrate in the subsequent analysis only on this dominant part of the rupture process.

For an event of this size, the point source model provides a surprisingly good fit to the data, indicating a short rupture length, although, it does not adequately match the amplitudes for stations from azimuths along the strike of the fault (Figure 4). Moreover, it fails to match the first motion polarities at KIP and AFI. Matching the first motion polarities for all stations simultaneously was not possible. Slight changes in the mechanism as the rupture propagates, as well as deviations from great circle paths of the rays, can affect the first motions for stations close to the P-wave nodes.

To determine the primary direction of the rupture propagation we introduce kinematic models with ruptures propagating unilaterally and bilaterally along the strike of the fault. A rupture velocity of $2.0 \mathrm{~km} / \mathrm{s}$ is used and the depth and source mechanism are fixed to the point source estimate; in each case we invert for the moment release along the fault. Since we have four stations along the strike of the fault (KIP and AFI to

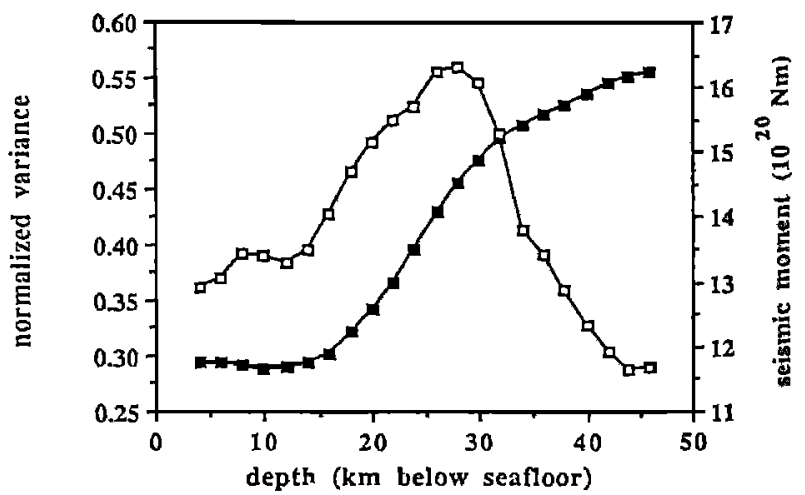

Fig. 2. Residual variance (filled squares) and seismic moment (open squares) as a function of centroid depth. 

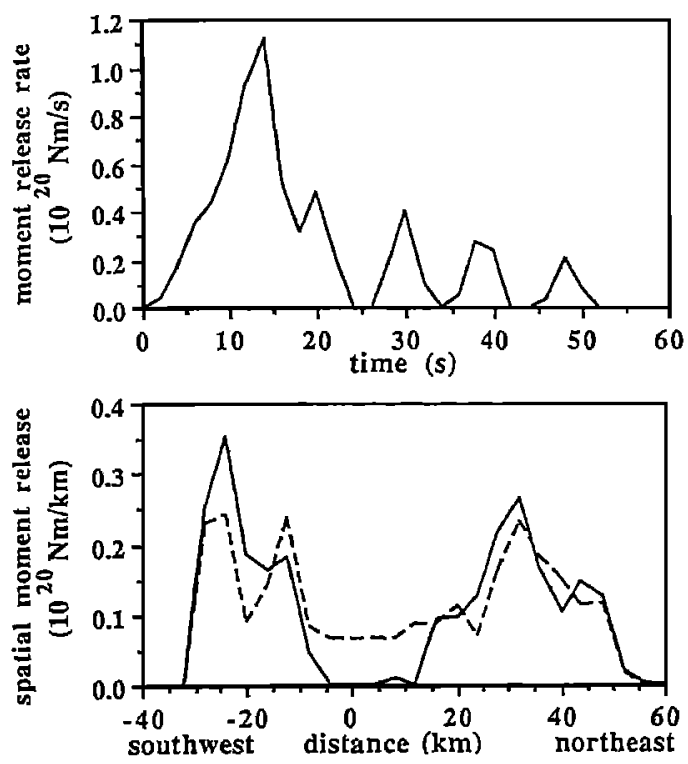

Fig. 3. a) Seismic moment release rate as a function of time (source time function) for best point source PS (Table 1). b) Seismic moment release along the fault length for the bilaterally propagating source BS2 (solid line) (Table 1) and a bilateral rupture model with additional slip in the epicentral region during later stages of the rupture (dashed line). Both models fit the data equally well.

the noth and CRZ and PAF to the south), rupture propagation effects should be detectable. A southwestward propagating rupture fits the data the least, whereas a rupture propagating towards northeast slightly improves the misfit compared to the point source solution. The best fit is obtained by a bilateral rupture, in which slightly more moment is released along the northward than the southward segment (Table 1). Figure 4 shows the matches to the data at representative stations.

Because the $P$ waves near the nodes continue to show substantial mismatch, we investigate the improvement that can be achieved by allowing variation in the mechanisms of the northward and southward segments. A small difference in dip. and rake appears to considerably improve the mismatch. The bilateral model with a small variation in dip and rake matches

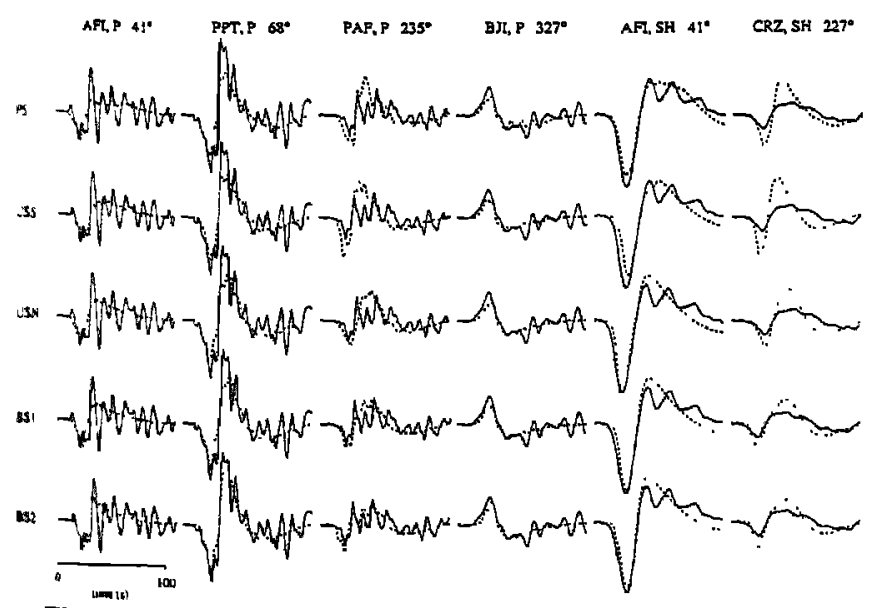

Fig. 4. Comparison of $\mathrm{P}$ and SH waveforms for different models listed in Table 1. Number next to the station code is the azimuth from the source. the waveforms and amplitudes better in the first 30-40 $\mathrm{s}$ than the other models. Later parts of the $P$ waveforms, probably contaminated by water reverberations (e.g. AFI P wave), are not modelled adequately by any of our models. Our final model (Figure 5 and Table 1 ) has the following parameters: the northern segment $\left(M_{0}=5.5 \times 10^{20} \mathrm{Nm}\right)$ has a strike of $212^{\circ}$, $\operatorname{dip} 82^{\circ}$ and rake $187^{\circ}$, and the rupture lasts about $30 \mathrm{~s}$, whereas the southward segment $\left(\mathrm{M}_{\mathrm{o}}=4.7 \times 10^{20} \mathrm{Nm}\right)$ has a strike of $210^{\circ}$, dip $95^{\circ}$, rake $174^{\circ}$, and rupture lasting about 16 s. The kinematic bilateral model indicates only very small moment release in the vicinity of the epicenter. The possibility of additional slip at the epicenter during later stages of the rupture is investigated by allowing the slip at the epicenter to occur at arbitrary time in a $25 \mathrm{~s}$ time frame and we find that additional slip might have occurred there. The estimated spatial distribution of the seismic moment for a bilateral rupture model with and without reslip in the epicentral area is shown in Figure 3b.
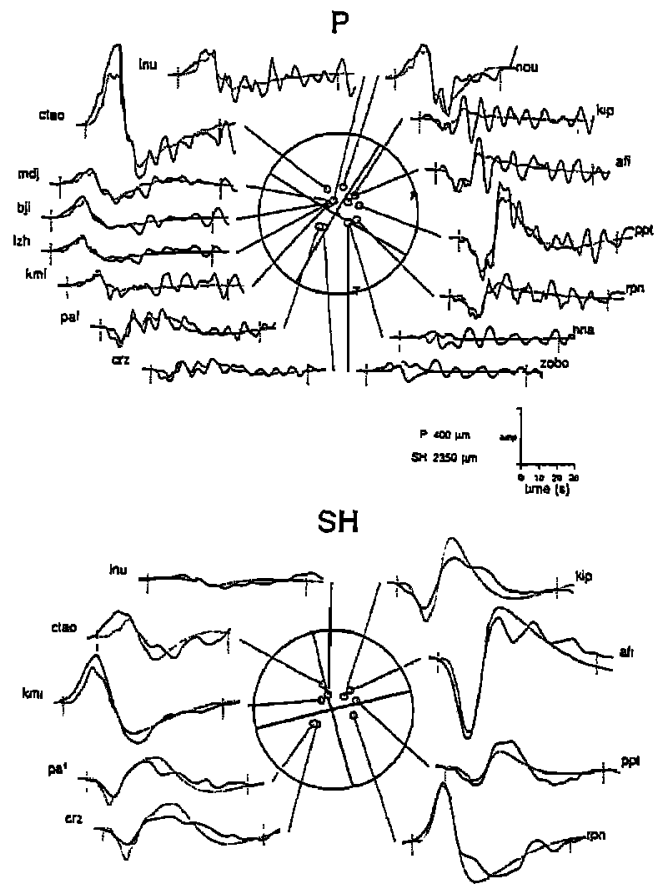

Fig. 5. Observed (solid) and theoretical (dashed) $\mathrm{P}$ and $\mathrm{SH}$ waves for the model BS2 in Table 1. Fault plane solution for the sum of the two subevents is shown at the center of the figure. Seismogram amplitudes are normalized to an epicentral distance of $40^{\circ}$.

\section{Summary and Discussion}

The centroidal solution indicates almost pure right-lateral strike-slip with a strike of $31^{\circ}$, which is in good agreement with the local trend of the ridge in the epicentral region where it has a strike of $33^{\circ}$. Global plate tectonic models predict a very similar direction of plate motion. The RM2 model of Minster and Jordan (1978) predicts an azimuth of $53^{\circ}$ and a rate of $2.7 \mathrm{~cm} / \mathrm{a}$, and the NUVEL-1 model (DeMets et al, 1990 ) assigns an aximuth of $41^{\circ}$ and a rate of $3.0 \mathrm{~cm} / \mathrm{a}$ for the plate motion in the epicentral region.

Our total seismic moment estimate is close to that of the 
long-period CMT solution $\left(14 \times 10^{20} \mathrm{Nm}\right)$. Our results show that about $80 \%$ of this moment was released in the first $24 \mathrm{~s}$ of the rupture process. Observable directivity due to rupture propagation is surprisingly sma11, partly due to short fault length and partly to bilaterally propagating rupture. A model with rupture propagating unilaterally towards northeast fits better than a model with a purely southwestward rupture. A bilaterally propagating rupture with a small variation in the source mechanisms between the southern and northern segments provides the best fit to the data. The length of the northeast segment is about $55 \mathrm{~km}$ and the seismic moment released along it is about $5.5 \times 10^{20} \mathrm{Nm}$. The southwest segment is shorter $(35 \mathrm{~km})$ and the seismic moment slightly lower $\left(4.7 \times 10^{20} \mathrm{Nm}\right)$.

Initially, only a small amount of moment was released in the epicentral region, but there is a possibility that the region reslipped during later stages of the rupture process. The initial low moment release in the epicentral region and the small difference in dip of the two fault segments suggest a possibility that the Macquarie Ridge earthquake nucleated near a geometric barrier formed by a small change in the dip of the fault. King and Nábělek (1985) and King (1986) showed that earthquakes often nucleate near fault bends or other geometrical complexities of the fault zone.

The rupture length of $90 \mathrm{~km}$ associated with the main moment release based on the bilateral rupture model is unusually short for an event of this magnitude. The tight cluster of the aftershocks (Figure 1) also indicates that the rupture probably did not extend more than $100 \mathrm{~km}$. The stress drop associated with the dominant $90 \mathrm{~km}$ of the rupture, taking the fault width of $20 \mathrm{~km}$ (twice the centroidal depth) and a seismic moment of $10.2 \times 10^{20} \mathrm{Nm}$, is $180 \mathrm{bar}$ and the average displacement is $17 \mathrm{~m}$. For a $100-\mathrm{km}$-long rupture and the total seismic moment of $13.4 \times 10^{20} \mathrm{Nm}$, these values are 210 bar and $20 \mathrm{~m}$. Hence the Macquarie Ridge earthquake shows one of the largest stress drops for interplate strike-slip events in this magnitude range (see Kanamori and Anderson, 1975). The relatively short fault length and large stress drop of this event may be related to the segmentation of the Macquarie Ridge in the epicentral region. Bathymetric charts of the epicentral region (Figure 1) show that the ridge is broken up into smaller segments, on the order of $50-100 \mathrm{~km}$ long. One of these topographic segments coincides with what we determined to be the region of the primary moment release during the 1989 event. Two thrust events (Banghar and Sykes, 1969; Harvard CMT solution) that occurred in 1966 and 1984 seem to bracket the region that broke in the strike-slip fashion during the 1989 event, indicating fault segmentation on the same order as seen in the topography. We submit therefore that the observed ridge segmentation relates to fault segmentation which confines ruptures to short segments.

Acknowledgements. We thank David Chavez for providing IDA data and Larry Ruff for providing GEOSCOPE data, which ultimately were contributed by Barbara Romanowicz.
David Reinert drafted the bathymetric map. This project was supported by the National Science Foundation grant EAR8896187.

\section{References}

Banghar, A. R., and L. R. Sykes, Focal mechanisms of earthquakes in the Indian Ocean and adjacent regions, $J$. Geophys. Res., 74, 632-649, 1969.

Boyd, T. M., and J. L. Nábělek, Rupture process of the Andreanof Islands Earthquake of May 7, 1986, Bull. Seism. Soc. Am., 78, 1653-1673, 1988.

DeMets, C., R. G. Gordon, D. F. Argus, and S. Stein, Current plate motions, Geophys. J. Int., in press.

Duncan, R. A., and R. Varne, The age and distribution of the igneous rocks of Macquarie Island, Pap. Proc. $R$. Soc. Tasm., 122(1), 45-50, 1988.

Kanamori, H., and D. L. Anderson, Theoretical basis of some empirical relations in seismology, Bull. Seism. Soc. Am 65, 1073-1095, 1975.

King, G. C. P., Speculations on the geometry of the initiation and termination processes of earthquake rupture and its relstion to morphology and geological structure, Pageoph, 124, 567-585, 1986.

King, G. C. P., and J. L. Nábělek, The role of bends in faults in the initiation and termination of earthquake rupture, Science, 228, 984-987, 1985.

Minster, J. B., and T. H. Jordan, Present-day plate motions, J. Geophys. Res., 83, 5331-5354, 1978.

Molnar, P., T. Atwater, J. Mammerickx, and S. M. Smith, Magnetic anomalies, bathymetry, and the tectonic evolution of the south Pacific since late Cretaceous, Geophys. J. R. Astr. Soc., 40, 383-420, 1975.

Nábělek, J. L., Determination of earthquake source parameters from inversion of body waves, Ph. D. Dissertation, $360 \mathrm{pp}$, Massachusetts Institute of Technology, Cambridge, 1984.

Ruff, L. J., J. W. Given, C. O. Sanders, and C. M. Sperber, Large earthquakes in the Macquarie Ridge Complex: Transitional tectonics and subduction initiation, Pageoph, 129, 71-129, 1989.

Stock, J., and P. Molnar, Uncertainties in the relative positions of the Australian, Antarctica, Lord Howe, and Pacific plates since the late Cretaceous, J. Geophys. Res., 87, 4697-4714, 1982.

Wiens, D.A., Bathymetric effects on body waveforms from shallow subduction zone earthquakes and application to seismic processes in the Kurile Trench, J. Geophys. Res., 94, 2955-2972, 1989.

J. Braunmiller and J. Nábžlek, College of Oceanography, Oregon State University, Corvallis, OR 97331

(Received March 19, 1990;

revised May 21, 1990;

accepted May 21, 1990) 